\title{
HUBUNGAN ANTARA KEMAMPUAN MEMUKUL BOLA KE TEMBOK DENGAN KETEPATAN SERVIS TANGAN ATAS BOLA VOLI PADA MAHASISWA STKIP ROSALIA LAMPUNG
}

\author{
Luh Eka Laba 1, Herlin Armisesna 2,* \\ STKIP Rosalia Lampung, Prodi \\ Pendidikan Olahraga, Jl. Soekarno \\ Hatta Mulyojati 16C Kota Metro, 34125 \\ *luhekalaba09@gmail.com¹, herlinarmisesna100@gmail.com
}

\begin{abstract}
Abstrak: Pendidikan jasmani merupakan bagian yang tak terpisahkan dari pendidikan secara keseluruhan. Dimana pendidikan jasmani merupakan suatu proses pembelajaran yang didesain untuk meningkatkan kebugaran jasmani, mengembangkan keterampilan motorik, pengetahuan dan hidup aktif dan sikap sportif melalui kegiatan pendidikan jasmani. Penelitian ini bertujuan untuk mengetahui hubungan antara kemampuan memukul bola ke tembok dengan ketepatan servis tangan atas bola voli pada mahasiswa STKIP Rosalia Lampung. Adapun manfaat dari penelitian ini, diharapkan bagi pihak universitas, program studi dan mahasiswa serta pelatih dan guru bola voli, agar dapat menyadari bahwa dalam permainan bola voli kemampuan memukul bola ketembok berperan menghasilkan ketepatan dalam melakukan servis tangan atas.
\end{abstract}

Metode penelitian yang digunakan dalam penelitian ini yaitu metode deskriptif. Populasi penelitian ini adalah mahasiswa STKIP Rosalia Lampunng yang mengikuti mata kuliah bola voli yang berjumlah 36 orang. Karena jumlah populasi <100 maka, sampel dalam penelitian ini adalah jumlah keseluruhan dari populasi yaitu $\mathbf{3 6}$ orang mahasiswa (total sampling). Berdasarkan hasil analisis yang diperoleh menunjukkan nilai $r_{\text {hitung }}=0,729>$ $r_{\text {tabel }}=0,329$, maka Ho ditolak, artinya ada hubungan yang signifikan antara kemampuan memukul bola ke tembok dengan ketepatan servis tangan atas bola voli pada mahasiswa STKIP Rosalia Lampung.

Kata Kunci:Kemampuan Memukul Bola, Ketepatan Servis, Bola Voli

Abstract: Physical education is an inseparable part of overall education. Where physical education is a learning process designed to improve physical fitness, develop motor skills, knowledge and active life and sportsmanship through physical education activities. This study aims to determine the relationship between the ability to hit the ball against the wall with the accuracy of hand service on volleyball in STKIP Rosalia Lampung students. As for the benefits of this research, it is hoped that universities, study programs and students as well as volleyball coaches and teachers will realize that in volleyball the ability to hit the wall plays a role in producing accuracy in serving the upper hand. The research method used in this research is descriptive method. The population of this study were students of STKIP Rosalia Lampung who took 36 volleyball courses. Because the population is $<100$, the sample in this study is the total number of the population, namely 36 students (total sampling). Based on the results of the analysis obtained, it shows the value of rcount $=0.729>$ rtable $=0.329$, then Ho is rejected, meaning that there is a significant relationship between the ability to hit the ball against the wall with the accuracy of hand service on volleyball in STKIP Rosalia Lampung students.

Keywords: Ball Strike Ability, Service Accuracy, Volleyball. 


\section{PENDAHULUAN}

Bola voli merupakan salah satu cabang olahraga yang populer dan banyak diminati oleh pelajar Indonesia dari semua golongan. Hal ini dapat dilihat dari animo pelajar sebagai pelaku maupun penonton dalam setiap pertandingan bola voli baik dari tingkat sekolah dasar, sampai perguruan tinggi atau dari tingkat daerah sampai ke tingkat nasional hal ini didukung oleh penelitian (Ismoko and Sukoco, 2013).

Bola voli adalah permainan yang dimainkan oleh dua regu, yang masing - masing terdiri dari enam orang dan dapat dilakukan di ruangan tertutup (indoor) dan terbuka (outdoor). Bola dimainkan di udara dengan melewati net, setiap regu hanya bisa memainkan bola maksimal tiga kali pukulan. Dalam bermain bola voli salah satu teknik yang harus dikuasai seorang pemain adalah servis. Servis merupakan pukulan pembukaan untuk memulai suatu permainan, namun jika ditinjau dari sudut taktik sudah merupakan suatu serangan awal untuk mendapatkan nilai agar suatu regu berhasil meraih kemenangan. Teknik servis yang baik adalah yang dapat menyukarkan lawan, bahkan diusahakan dapat langsung menghasilkan point.

Macam - macam teknik dan variasi servis antara

lain:

1. Servis tangan bawah.

2. Servis tangan atas.

3. Servis tangan samping.

4. Servis dengan melompat ( jumping service)

Dari uraian di atas teknik servis merupakan teknik yang digunakan untuk menyerang dan mendapatkan angka. Sedangkan tiap jenis servis mempunyai kelebihan dan kekurangan masing - masing. Salah satu teknik servis yang sering digunakan sebagai variasi serangan awal adalah servis tangan atas bola voli.

Servis tangan atas bola voli adalah salah satu teknik yang sulit dikuasai oleh seorang pemain, namun teknik ini efektif dalam memperoleh angka kemenangan.

Dalam melakukan servis tangan atas dibutuhkan ketepatan memukul yaitu perkenaan telapak tangan pada permukaan bola, sehingga apabila tepat perkenaannya, maka akan lebih mudah bagi pemain untuk mengarahkan bola ke tempat yang dia inginkan. Untuk meningkatkan ketepatan memukul tersebut dapat dilatih dengan latihan memukul bola ke tembok. Latihan memukul bola ke tembok diyakini dapat berperan penting dalam menghasilkan ketepatan dalam memukul bola voli.

Kemampuan memukul bola voli ke tembok merupakan proses belajar motorik yang dapat membentuk koordinasi gerak tangan, serta diyakini dapat meningkatkan ketepatan dalam gerakan memukul bola. Dengan demikian pemain yang mempunyai koordinasi memukul bola voli ke tembok yang baik dapat diasumsikan pemain tersebut dalam melakukan servis tangan atas bola voli akan baik pula.

Adanya hubungan antara kemampuan memukul bola ke tembok dengan ketepatan servis tangan atas perlu dibuktikan kebenarannya. Berkaitan dengan hal tersebut penulis tertarik untuk melakukan penelitian pada mahasiswa STKIP Rosalia Lampung. 


\section{METODE PENELITIAN}

\section{A. Metode Penelitian}

Metode penelitian merupakan strategi umum yang di anut dalam pengumpulan data dan analisis data yang diperlukan, guna menjawab persoalan yang dihadapi. Penelitian menggunakan metode deskriptif korelasional tentang, hubungan antara kemampuan memukul bola ke tembok dengan ketepatan servis tangan atas bola voli pada mahasiswa STKIP Rosalia Lampung. Hal ini didukung oleh penelitian Wachyu Bakti

(Bakti Bachtiar and Kastrena, 2019)

Metode penelitian yang digunakan adalah deskriptif korelasional karena metode ini digunakan untuk memperoleh informasi - informasi mengenai keadaan saat ini dengan melihat hubungan antara variabel yang ada. Penelitian deskriptif lebih spesifik dengan memusatkan perhatian kepada aspek - aspek tertentu dan sering menunjukkan hubungan antar berbagai variabel". Metode ini juga dilakukan oleh (Achmad, 2018)

\section{B. Variabel Penelitian}

Variabel adalah objek penelitian atau apa yang menjadi tititk perhatian suatu penelitian (Suharsimi Arikunto, 2002). Yang menjadi titik perhatian dalam penelitian ini adalah :

1. variable bebas $(\mathrm{X})$

yaitu kemampuan memukul bola voli ke tembok.

2. variable terikat $(y)$

yaitu servis tangan atas bola voli

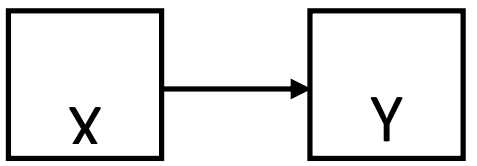

\section{Gambar 1. Hubungan antara kemampuan memukul bola voli ke tembok $(X)$ dengan ketepatan servis tangan atas bola voli $(\mathrm{Y})$.}

\section{Definisi Operasinol Variabel}

Definisi operasional variabel berguna untuk membatasi dan mengarahkan ruang lingkup variabel yang diamati dengan menggunakan instrumen yang telah dikembangkan, adapun definisi operasional variabel dalam penelitian ini adalah

1. Kemampuan memukul bola ketembok adalah untuk membentuk terjadinya koordinasi tubuh yang baik setelah melakukan tes keterampilan kemampuan memukul bola voli ketembok.

2. Ketepatan servis tangan atas adalah hasil yang diperoleh mahasiswa setelah melakukan tes servis tangan atas bola voli. 


\section{Populasi dan Sampel}

\section{Populasi}

Populasi dalam penelitian ini adalah mahasiswa STKIP Rosalia Lampung sebanyak 36 mahasiswa.

\section{Sampel}

Sampel dari penelitian ini adalah sebanyak 36 mahasiswa.

\section{E. Teknik Pengumpulan Data}

Teknik yang digunakan untuk mengumpulkan data dalam penelitian ini adalah dengan menggunakan tes. Data yang diperoleh melalui pengukuran masing - masing tes. Tes dan pengukuran ketepatan

servis menggukan tes servis tangan atas bola voli, dilakukan sebanyak 6 kali dan 4 yang terbaik yang diambil. Sedang untuk tes dan pengukuran kemampuan memukul bola ke

tembok menggunakan tes kemampuan memukul bola voli ke tembok selama 30 detik.

\section{F. Instrumen Penelitian}

Instrument adalah alat yang digunakan dalam suatu penelitian. Instrumen dalam penelitian ini adalah menggunakan tes instrumen standar yaitu ketepatan servis tangan atas bola voli dan tes kemampuan memukul bola voli ke tembok dengan validitas sebesar 0,82 serta reliabilitas sebesar 0,89 .

\section{Tempat dan Waktu}

Penelitian ini dilaksanakan dilapangan bola voli STKIP Rosalia Lampung selama bulan September sampai November.

\section{Alat dan Bahan}

Untuk tes dan pengukuran servis tangan atas alat dan bahan yang digunakan yaitu sebagai berikut :
a. Kapur atau tali rafia yang digunakan sabagai garis.
b. Peluit
c. Bola voli
d. Lapangan bola voli dan net
e. Alat tulis untuk mencatat.

\section{Pelaksanaan}

Tes dan pengukuran ketepatan servis tangan atas bola voli : 
Testee berada dalam daerah servis dan melakukan servis yang sah sesuai dengan peraturan permainan yang berlaku untuk servis. Bentuk pukulan servis adalah menggunakan servis tangan atas. Kesempatan melakukan servis sebanyak 6 kali, dan untuk penilaian setiap servis ditentukan oleh tingginya bola waktu melampaui jaring dan angka sasaran dimana bola jatuh

a. Bola yang melampaui jaring di antara batas atas jaring dan tali yang direntangkan $50 \mathrm{~cm}$ dari padanya, mendapat nilai angka sasaran dikalikan 3 (tiga).

b. Bola yang melampaui jaring di antara kedua tali yang direntangkan, mendapatkan nilai angka sasaran dikalikan 2 (dua).

c. Bola yang melampaui jaring lebih tinggi dari tali yang tertinggi, mendapat nilai sama dengan angka sasaran.

d. Bola yang dimainkan dengan cara tidak sah, misalnya bola jatuh diluar sasaran atau testee melewati garis servis maka mendapat nilai 0 (nol).

e. Hasil yang dicatat adalah jumlah angka dari empat nilai hasil perkalian yang terbaik.

Tes dan pengukuran kemampuan memukul bola ketembok:

Tes dan pengukuran kemampuan memukul bola ketembok ini dilaksanakan di dinding pantul bola voli STKIP Rosalia Lampung selama bulan September sampai November 2019. Teste berdiri di belakang garis pembatas berjarak $2 \mathrm{~m}$, kemudian melakukan gerakkan memukul bola ketembok selama 30 detik, untuk penilaian setiap bola yang memantul dan dapat dipukul diatas kepala dihitung satu point.

\section{HASIL DAN PEMBAHASAN}

Penelitian ini dilaksanakan di lapangan bola voli STKIP Rosalia Lampung selama bulan September sampai November dan membahas hubungan antara kemampuan memukul bola ke tembok dengan ketepatan servis tangan atas bola voli. Jumlah sampel dalam penelitian ini berjumlah 36 mahasiswa. Pengambilan data pada selama bulan September sampai November.

Data pada penelitian ini dianalisis dengan korelasi product moment.

\section{Deskripsi Data Kemampuan Memukul Bola Ke Tembok}

Deskriptif data pada penelitian ini meliputi nilai rata - rata, nilai standar deviasi, nilai tertinggi dan nilai terendah berikut data lengkapnya.

Tabel 1. Deskriptif Data Penelitian

\begin{tabular}{|l|l|l|}
\hline \hline Variabel & $\mathrm{X}$ & $\mathrm{Y}$ \\
\hline Nilai terendah & 28 & 2 \\
\hline Nilai tertinggi & 10 & 38 \\
\hline Rata - rata & 18,083 & 16,527 \\
\hline Standar deviasi & 5,406 & 9,145 \\
\hline
\end{tabular}




\begin{tabular}{|l|l|l|}
\hline Varian & 29,221 & 83,628 \\
\hline
\end{tabular}

Berdasarkan hasil pengolahan data primer diperoleh nilai rata - rata kemampuan memukul bola ke tembok 18,083 dengan nilai standar deviasi 5,406 . Selanjutnya berdasarkan klasifikasi kemampuan memukul bola ke tembok diperoleh data frekuensi seperti tersaji pada tabel 1 dibawah ini,

Tabel 2. Sebaran Frekuensi Jumlah Responden Berdasarkan Kemampuan Memukul Bola Ke Tembok

\begin{tabular}{|l|l|l|l|}
\hline \hline Skor & Rentang & $\begin{array}{l}\text { Frekwensi } \\
\text { (orang) }\end{array}$ & Persentase (\%) \\
\hline$>7$ & Kurang & 0 & 0 \\
\hline $14-8$ & Cukup & 11 & 30,56 \\
\hline $21-15$ & Baik & 17 & 47,22 \\
\hline $28-22$ & Baik Sekali & 8 & 22,22 \\
\hline$<29$ & Sempurna & 0 & 0 \\
\hline & & 36 & 100,00 \\
\hline
\end{tabular}

Dari tabel di atas terlihat bahwa secara umum responden berada pada klasifikasi baik yaitu 47,22\% hal ini ditunjukkan sebanyak 17 responden berada pada interval tersebut, sedangkan responden yang memiliki klasifikasi cukup adalah sebanyak 30,56\% (11 responden) dan 22,22\% (8 responden) memiliki kategori baik sekali. Distribusi frekuensi jumlah mahasiswa berdasarkan klasifikasi juga dapat dilihat pada grafik dibawah ini

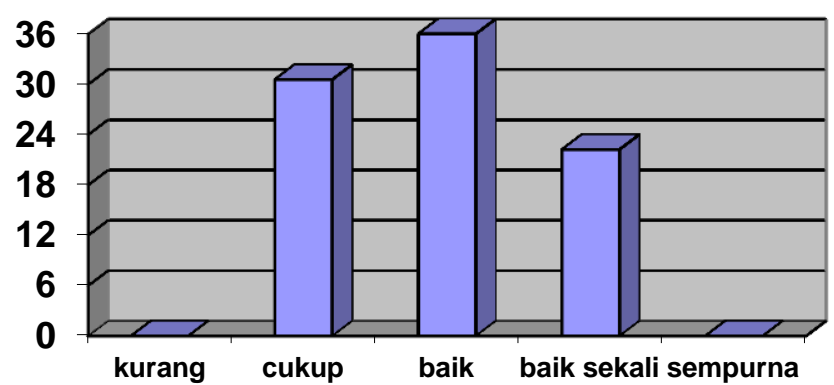

Gambar 4. Distribusi frekuensi jumlah mahasiswa berdasarkan kemampuan memukul bola voli ke tembok 
Gambar grafik tersebut menunjukkan kemampuan memukul bola ketembok pada mahasiswa STKIP Rosalia Lampung sudah masuk dalam kategori baik, hal ini dapat dilihat dari 36 mahasiswa yang termasuk dalam golongan tersebut sebanyak 17 mahasiswa, 8 yang masuk dalam klasifikasi baik sekali dan 11 mahasiswa dalam klasifikasi cukup.

\section{Deskripsi Data Ketepatan Servis Atas Bola Voli}

Berdasarkan hasil pengolahan data primer diperoleh rata - rata ketepatan servis atas bola voli 16,527 dengan standar deviasi 9,145 . selanjutnya berdasarkan klasifikasi ketepatan servis atas bola voli diperoleh data frekuensi seperti tersaji pada tabel 2 dibawah ini;

Tabel 3. Sebaran Frekueinsi Jumlah Responden Berdasarkan Ketepatan Servis Atas Bola Voli

\begin{tabular}{|l|l|l|l|}
\hline \hline Skor & Rentang & Frekwensi (orang) & Persentase (\%) \\
\hline$>11$ & Kurang & 12 & 33,33 \\
\hline $22-12$ & Cukup & 15 & 41,67 \\
\hline $33-23$ & Baik & 8 & 22,22 \\
\hline $44-34$ & Baik Sekali & 1 & 2,78 \\
\hline$<45$ & Sempurna & 0 & 0 \\
\hline & & 36 & 100,00 \\
\hline
\end{tabular}

Dari tabel di atas terlihat bahwa secara umum responden berada pada klasifikasi cukup yaitu $41,67 \%$ hal ini ditunjukkan sebanyak 15 responden berada pada interval tersebut, sedangkan responden yang memiliki klasifikasi kurang adalah sebanyak $33,33 \%$ (12 responden), responden yang memiliki klasifikasi baik adalah sebanyak 22,22\% (8 responden) dan 2,78\% (1 responden) memiliki kategori baik sekali.

Distribusi frekuensi jumlah mahasiswa berdasarkan klasifikasi juga dapat dilihat pada grafik dibawah ini;

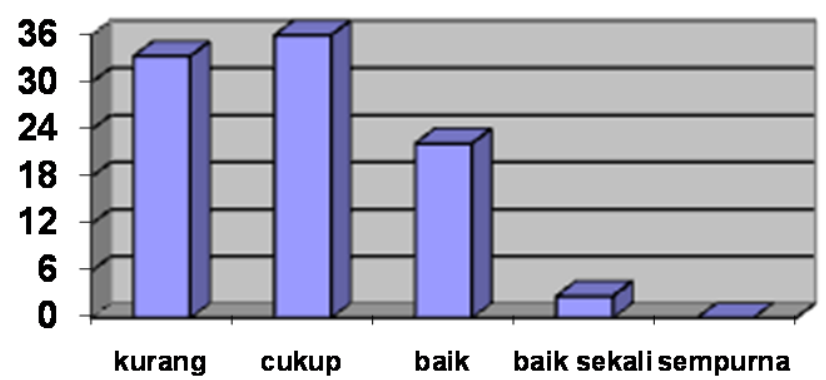

Gambar 5. Distribusi Frekuensi Jumlah Mahasiswa Berdasarkan Ketepatan Servis Atas Bola Voli 
Gambar grafik di atas menunjukkan ketepatan servis tangan atas bola voli pada mahasiswa STKIP Rosalia Lampung sudah masuk dalam kategori cukup, hal ini dapat dilihat dari 36 mahasiswa yang termasuk dalam golongan tersebut sebanyak 15 mahasiswa, 8 yang masuk dalam klasifikasi baik, 1 yang masuk dalam klasifikasi baik sekali dan 12 mahasiswa perlu adanya peningkatan dalam pembelajaran masuk dalam klasifikasi kurang.

\section{Uji Hipotesis}

Hipotesis yang diajukan pada penelitian ini adalah adanya hubungan antara kemampuan memukul bola ke tembok dengan ketepatan servis tangan atas bola voli. Untuk menguji hipotesis tersebut maka analisis data yang digunakan adalah teknik analisis data product moment dengan kriteria uji $r$. Hasil pengujian hipotesis dapat dilihat pada tabel dibawah ini.

Tabel 4. Hasil pengujian hipotesis

\begin{tabular}{|l|l|l|l|}
\hline \hline$r_{\text {hitung }}$ & $r_{\text {tabel }}$ & Uji Hipotesis & Kesimpulan \\
\hline 0,729 & 0,329 & Ho ditolak & signifikan \\
\hline
\end{tabular}

Berdasarkan tabel diperoleh nilai yaitu $r_{\text {hitung }}>r_{\text {tabel }}$ atau 0,729 $>0,329$ maka $h_{0}$ ditolak dan $\mathrm{h}_{1}$ diterima, artinya terdapat hubungan antara kemampuan memukul bola ke tembok dengan ketepatan servis tangan atas bola voli

\section{Pembahasan}

Dalam permainan bola voli servis merupakan awal terjadinya suatu permainan, akan tetapi dalam perkembangannya kemudian servis menjadi salah satu serangan pertama yang sangan penting. Keberhasilan dalam melakukan

servis tangan atas harus didukung dengan adanya kekuatan serta koordinasi gerakan yang baik. Berdasarkan hasil analisis secara statistik menunjukkan terdapat hubungan kemampuan memukul bola ke tembok dengan ketepatan servis tangan atas bola voli. Hasil analisis ini menunjukkan bahwa kemampuan memukul bola voli ketembok merupakan faktor yang dapat mempengaruhi ketepatan dalam melakukan servis tangan atas bola voli. Adanya hubungan antara kemampuan memukul bola ke tembok dengan ketepatan servis tangan atas bola voli disebabkan bahwa kemampuan memukul bola ke tembok dapat menentukan koordinasi gerakan tubuh serta dapat menambah kekuatan tangan dalam melakukan servis tangan atas, dan servis tangan atas dapat dikatakan sebagai modal awal dalam memulai suatu pertandingan bola voli.

Gerakan kemampuan memukul bola ke tembok merupakan serangkaian gerak yang dapat menghasilkan koordinasi gerakan yang baik dalam memperbaiki koordinasi tubuh serta meningkatkan ketepatan dalam melakukan gerak. Semakin baik mahasiswa dalam melakukan kemampuan memukul bola ke tembok semakin baik pula dalam hasil servis tangan atas bola voli. Servis adalah pukulan awal yang dilakukan oleh pemain belakang kanan yang dilakukan didaerah servis langsung ke lapangan lawan. Faktor - faktor yang mempengaruhi keberhasilan servis bergantung pada kecepatan bola, jalan dan putaran bola, koordinasi gerakan serta penempatan bola ke tempat kosong didaerah permainan lawan (Sovensi, 2018)

Berdasarkan uraian di atas semakin memperjelas bahwa 
salah satu faktor yang menentukan ketepatan servis tangan atas bola voli adalah kemampuan memukul bola ketembok. Hal ini terbukti pada penelitian ini, hasil analisis secara statistik menunjukkan bahwa ada hubungan yang signifikan antara kemampuan memukul bola ketembok deengan ketepatan servis tangan atas bola voli.

\section{KESIMPULAN}

Berdasarkan hasil penelitian yang dibuktikan dengan hasil analisis data maka penelitian ini dapat disimpulkan bahwa: Terdapat hubungan yang signifikan antara kemampuan memukul bola ke tembok dengan ketepatan servis tangan atas bola voli pada mahasiswa STKIP Rosalia Lampung.

\section{DAFTAR PUSTAKA}

Arikunto, Suharsimi. 2002. Prosedur Penelitian. Jakarta : P.T. Rineka Cipta.

Achmad, I. Z. (2018) 'Uji Validitas dan Reliabilitas Tes Passing Atas dan Passing Bawah Pada Cabang Olahraga Bola Voli', Jurnal Speed (Sport, Physical Education, Empowerment), 1(1), pp. $51-57$.

Bakti Bachtiar, W. and Kastrena, E. (2019) 'Hubungan Antara Daya Ledak Otot Lengan Dengan Kemampuan Smash Bola Voli Pada Ekstrakurikuler', Maenpo, 9(1), p. 18. doi: 10.35194/jm.v9i1.904.

Ismoko, A. P. and Sukoco, P. (2013) 'Pengaruh Metode Latihan Dan Koordinasi Terhadap Power Tungkai Atlet Bola Voli Junior Putri', Jurnal Keolahragaan, 1(1), pp. 1-12. doi: $10.21831 / \mathrm{jk} . \mathrm{v} 111.2339$.

Sovensi, E. (2018) 'Ketepatan Smash Pemain Bolavoli Siswa SMA Ditinjau dari Koordinasi Mata-Tangan dan Extensi Togok', Gelanggang Olahraga: Jurnal Pendidikan Jasmani dan Olahraga (JPJO), 2(1), pp. 129-139. doi: 10.31539/jpjo.v2i1.406. 